published by the British Baking Industries Research Association at the modest price of $10 s$. (Report No. 72: Some General Principles of Bakery Planning. By Mr. D. E. Chapman and Miss E. M. Laing. Pp. ii +82 . Chorleywood, Rickmansworth: British Baking Industries Research Association, 1964. 10s.). It may be added that the British Baking Industries Research Association reports are not normally available to the public, but an exception has been made with this one, as it was felt to be one of general interest. The report attempts to answer in advance and in order the questions which an intelligent baker would ask in these circumstances. Thus, after some preliminary advice to the baker confronted with the dilemma of whether to adapt his existing bakery or build an entirely new one, the authors guide him through the intricacies of site-choosing, and introduce him to the complexities of lay-out and planning. The foreword makes it clear, however, that, except for small projects, he will need the services of an architect; and the report is intended to help in the liaison with the latter rather than to displace him. The design of individual parts of the bakery is discussed in detail, and includes ancillary services such as the despatch area, test-laboratory and boiler room: even the refuse store is not forgotten. Special attention is directed throughout to considerations of safety, to cemfortable working corditions, ard to the reduction of unnecessary labour: reference is made in an appendix to appropriate legislation.

\section{Hydatid Diseases in New Zealand}

Hydatid disease in New Zealand is as old as the sheep industry. A circular from Dunedin in 1887 to medical practitioners revealed that nearly all, oven at that time, had wide experience of the disease. Such a well-entrenched disease will not readily be overcome, and reports of past efforts at eradication are conflicting. It was with this knowledgo that the National Hydatids Council asked Dr. F. S. Maclean to write a history of the fight against hydatid disease in New Zealand (Hydatid Disease in New Zealand: an Account of the Events leading to the Establishment of the National Hydatids Council, and the Methods adopted to Eradicate the Disease. By F. S. Maclean. Pp. 48. Wellington, N.Z.: National Hydatids Council, 1964). The lessons that emerge from his report are striking, and they are useful in ficlds far wider than hydatid prevention alone. First, there has been no sudden or dramatic advance in medical knowledge. The methods advocated in the 1880's-never to allow dogs to feed on raw offal-are just the same as those advocated to-day. Secondly, the problem is one of people rather than dogs and other animals. For nearly a hundred years many efforts have been made to bring knowledge of hydatid disease and the methods of prevention to all New Zealanders, and many thousands of pounds have been spent. On two occasions at least, regulations have been framed and passed to stop dogs eating raw offal. As a result, many thousands of New Zealanders knew the truth about hydatid disease but took no action to check it. Some felt that any action taken by the individual was made useless by the carelessness of others. Some had a quite unrealistic belief that dosing with arecoline would, in some miraculous way, relieve them from the responsibility of preventing their dogs from eating raw offal.

In spite of every effort by the Government, the various Government departments, the medical schools, the research units and the medical profession, hydatid disease continued to take its yearly toll of health and life. Apathy and hopelessness fed on confused thinking, stories of failure and avoidance of personal responsibility. As indicated by Dr. Maclean, the atmosphere in 1957 suddenly changed. There was a dramatic upsurge of interest. For the first time farmers worked individually to eliminate the disease from their own farms, they co-operated with their neighbours to form local anti- hydatid committees, they elected members to fight the disease at a provincial level and, in conjunction with the Federation of Young Farmers Clubs, they fin ally prevailed on the Government of the day to form a national body to campaign against hydatid disease in all parts of the country. The change in attitude was due to participation. Farmers were told of a disease which primarily affected them and were told of methods of $p$ revention which only they could apply. They were given responsi bility for action, were asked to make their own decisions. plan their own policies and become involved themselves in a campaign they could call their own. Organizations and individual farmers devised methods of disposing of or treating offal, destroying carcases, controlling dosing, and feeding their dogs. Local committees tcok the message to every local dog owner. District committecs defined boundaries and co-ordinated the work of lccal committees. Within two years approximately 500 lccal committees were set up in rural areas throughout New Zealand. Later, a National Hydatids Council was formed: its success is described in the booklet.

\section{Protein Requirements of Man}

IN 1963 the World Health Organization and the Food and Agriculture Organization requested the views of experts on various aspects of protein metabolism. Following on this request a working party was set up, under the chairmanship of Prof. F. G. Young, to investigate the human requirements of protein with special reference to the dietary background of the United Kingdom; the report of this working party has recently been published (Reports on Public Health and Medical Subjects, No. 111: Requirements of Man for Protein. Pp. vi+90. London: H.M.S.O., 1964. 5s. 6d. net). Physiological variations which can occur in protein metabolism and regulation are dealt with in the report, which then discusses the nutritive value of proteins both in relation to the composition of the proteins and the calorific value of the diet. The relationship between different forms of biological assay of protein quality is discussed and the importance of 'nitrogen balance' mothods is emphasized. Factors which affect the nutritive value of protein foods are considered and human factors which affect the requiroments are discussed at length, while the effects of disease and injury are reviewed briefly. The mean lower and upper limits of dietary protein intake per day for all age-groups are summarized and suggestions are made as to the use of such data in the recommendation of protein allowances. The report concludes with a number of appendixes dealing with specialized aspects of protein supply and requirements.

\section{The Ramsay Memorial Fellowships Trust:}

Fellowships for Advanced Students of Chemistry

Applications for two Ramsay Memorial fellowships for advanced students of chemistry will be considered in February 1965. One of the fellowships will be limited to candidates educated in Glasgow, but they can apply to be considored for both fellowships. The value of each fellowship will be $£ 750$ per annum, to which may be added a grant for expenses of research not exceeding $£ 150 \mathrm{per}$ annum, and will normally be tenable for two years.

\section{Travel Grants}

Applications for three Ramsay travel grants for the year 1965-66 will also be considered in February 1964. No travel grant will exceed $£ 500$. Two of the travel grants will be limited to junior academic chemistry staff of universities and colleges of technology or advanced technology in England, Wales and Northern Iroland. One travel grant will be limited to junior academic chemistry staff of universitios in Scotland.

Further information concerning fellowships and grants can be obtained from the Joint Honorary Secretarios, 